\title{
Behavior of Liquid Phase Formation during Iron Ores Sintering
}

\author{
Xuewei LV, ${ }^{1)}$ Chenguang BAI, ${ }^{2)}$ Qingyu DENG, ${ }^{3)}$ Xiaobo $\mathrm{HUANG}^{3)}$ and Guibao QIU ${ }^{1)}$ \\ 1) School of Materials Science and Engineering, Chongqing University, 400044 China. E-mail: Ivxuewei@163.com \\ 2) School of Materials Science and Engineering, Chongqing University, 400044 China. E-mail: bguang@cqu.edu \\ 3) Master Student in School of Materials Science and Engineering, Chongqing University, 400044 China.
}

(Received on November 4, 2010; accepted on January 28, 2011)

\begin{abstract}
The improvement of industrial parameters like the basicity and sintering temperature and the selection of raw materials to form the acicular calcium ferrites become the hot topic in sintering production. However, the experimental with the sintering pot in the laboratory is still a main method up to now, no effective mathematical model or experience equations were developed. Factsage is a software for thermodynamic calculation in ironmaking and steelmaking. In present study, Factsage was used to calculate the liquid phases formulation during the sintering. The effect of the chemical compositions on the liquidus projection was also discussed. It was found that the content of liquid phase formed is about $25 \%-$ $70 \%$ at $1250^{\circ} \mathrm{C}$ due to their chemical composition. The more $\mathrm{SiO}_{2}$, the easier to form liquid phase. The experiments were carried out for the validation. It was found that the calculations of the mass of liquid phase generation cannot give a very good and accurate agreement with the measurement of the melting behavior of the sample quantificationally, however, for the ability of the liquid phase formation during the sintering, the calculations can give a good qualitative results, especially in the temperature of melting begin and the temperature of $50 \%$ shrinkage. The calculations reported in this study can be used to estimate the sintering behavior of the iron ores under a certain industrial condition to reduce the extra experiments. The experiments also shows that the calculations by Factsage can give some good explanations on the phenomenon of the melting behavior of different samples.
\end{abstract}

KEY WORDS: sintering; thermodynamic calculation; evaluation; calcium ferrite.

\section{Introduction}

The iron ore sinter production was developed from sinter with low basicity to sinter with high basicity in 1980's. The main reason for this is that a heterogeneous texture consisting primarily of relict porous hematite ore bonded by acicular (or needle shaped) calcium ferrites which is reported to be optimal for ironmaking in blast furnace. ${ }^{1-3)}$ There are many excellent characters for such structure. For example, excellent reduction properties leading to low coke consumption in the blast furnace; good physical strength; acceptable reduction degradation properties; and superior high temperature reduction and melting properties. ${ }^{4-7)}$ The improvement of industrial parameters and the selection of raw materials to form acicular calcium ferrites become the hot topic in sintering production. Based on the theory of forming acicular calcium ferrites, a conception of classification was proposed by $\mathrm{Wu}$ and coworkers, ${ }^{8-11)}$ which includes assimilation, fluidity of liquid phase, self-intensity of adhere phase, and creating ability of calcium ferrite containing $\mathrm{SiO}_{2}$ and $\mathrm{Al}_{2} \mathrm{O}_{3}-\mathrm{SFCA}$ $\left(\mathrm{SiO}_{2}-\mathrm{Fe}_{2} \mathrm{O}_{3}-\mathrm{CaO}-\mathrm{Al}_{2} \mathrm{O}_{3}\right)$. These four indexes can give a comprehensive estimation of the behavior of iron ore during sintering. However, these indexes can only be measured in a special equipments and the value of the index is a relative data. Up to now, the most effective method on studying the iron ore sintering process is the experiments in the laboratory which is carried out in the sintering pot. ${ }^{9,12,13)}$ No mathe- matical model or experience equations were developed. It is known that the experiment in sintering pot consumes a lot of raw materials and labor, in additions, the experiments are always limited, and the comprehensive understanding of the sintering process is never achieved only depending on the experiments. It means that the judgment of the iron ore still mostly depend on the laboratory experiments other than the theory calculations based on the thermodynamic data. Therefore, the study on how to estimate the sintering behavior of the raw materials in different conditions by the theoretical calculation is of vital importance, and the development of this will greatly improve the sintering production. Factsage is a software for thermodynamic calculation, especially in ironmaking and steelmaking. In present study, Factsage will be used to calculate the liquid phases formulation during the sintering. The effect of the chemical composition on the liquid phase and the liquids projection was also discussed. Actually, the reactions in the real industrial sintering plant are not uniform, and are governed by the rate limiting process. How much is this difference between the equilibrium state and the non-equilibrium states at all? The experiments were carried for examining this difference.

\section{Thermodynamic Calculation on Liquid Phase For- mation}

Eight iron ores were selected in this study, whose che- 
mical compositions are shown in Table 1. According to TFe and $\mathrm{FeO}$ in Table 1 the mass of $\mathrm{Fe}_{3} \mathrm{O}_{4}$ and $\mathrm{Fe}_{2} \mathrm{O}_{3}$ in each ore are calculated out. The $\mathrm{CaO}$ will be added into each ore to modify the basicity of the mixture as 2.0 for each ore. It was assumed that the total mass of all the $\mathrm{Fe}_{2} \mathrm{O}_{3}, \mathrm{Fe}_{3} \mathrm{O}_{4}, \mathrm{SiO}_{2}$, $\mathrm{MgO}, \mathrm{CaO}$, and $\mathrm{Al}_{2} \mathrm{O}_{3}$ is 100 gram. Therefore, the chemical composition of ores for calculation with Factsage is shown in Table 2.

It is important to point out that there is no solution databases for SFCA in Factsage up to now. The main reactions happened during the sintering is the liquid phase reaction, which is similar to the generation of slag, and the solid reactions happened among $\mathrm{CaO}, \mathrm{MgO}, \mathrm{FeO}, \mathrm{SiO}_{2}$ and etc.. In present study, the FToxid-SLAGA was selected to calculate the liquid phase generation during the sintering. The FToxid$\mathrm{MeO}$ was selected to calculate the solid phase reactions which appear among the $\mathrm{FeO}, \mathrm{MgO}, \mathrm{CaO}$, and $\mathrm{MnO} .{ }^{14)}$ The FToxid-WOLLA and FToxid-bC2S were selected to calculate the solid reactions which produce $\mathrm{CaSiO}_{3}$, dilute $\mathrm{MgSiO}_{3}$ and $\mathrm{FeSiO}_{3}$, and $\mathrm{Ca}_{2} \mathrm{SiO}_{4}$. The FToxid-OlivA and FToxid-cPyr were selected to calculate the complex silicate like olivine and clinopyroxene. In order to examine the solid reactions in which the calcium ferrite is produced, the FToxidCAF2, FToxid-CA2F, and FToxid-CAF were selected to calculate the possibility of generation of solid $\mathrm{Ca}_{2} \mathrm{Fe}_{2} \mathrm{O}_{5}$, $\mathrm{CaFe}_{4} \mathrm{O}_{7}$, and $\mathrm{CaFe}_{2} \mathrm{O}_{4}$. All the oxides like $\mathrm{Fe}_{2} \mathrm{O}_{3}, \mathrm{Fe}_{3} \mathrm{O}_{4}$, $\mathrm{CaO}, \mathrm{MgO}, \mathrm{SiO}_{2}$ etc. in the raw materials used in the calculations were selected from the compound database of FToxid. The detail introduction of these above databases can be found in the software or the website of the software. ${ }^{14)}$ The results will be validated by the high temperature experiments. The reactions happening in the eight mixtures from $400^{\circ} \mathrm{C}$ to $1300^{\circ} \mathrm{C}$ in the step of $50^{\circ} \mathrm{C}$ were calculated. The results were shown as followings.

\subsection{Liquid Phases Formulation}

The mass of liquid phase created with increasing the temperature was shown in Fig. 1. It shows that the mass of liquid phase increases with increasing the temperature. Ores $\mathrm{G}$ and $\mathrm{H}$ generated liquid phase at $1000^{\circ} \mathrm{C}$; and that for ore $\mathrm{C}$ is $1050^{\circ} \mathrm{C}$, for ore $\mathrm{A}, \mathrm{D}$, and $\mathrm{E}$ is $1100^{\circ} \mathrm{C}$, for ore $\mathrm{B}$ and $\mathrm{F}$ is $1150^{\circ} \mathrm{C}$. The mass of liquid phase generated in ore $\mathrm{G}$ increases dramatically after $1200^{\circ} \mathrm{C}$, it reaches more than $80 \%$ at $1250^{\circ} \mathrm{C}$, and $90 \%$ in mass at $1300^{\circ} \mathrm{C}$. Ores $\mathrm{A}$ and $\mathrm{E}$ can also generate much liquid phase above $1200^{\circ} \mathrm{C}$, almost $80 \%$ at $1300^{\circ} \mathrm{C}$. Ore $\mathrm{F}$ generate much less liquid phase than other ores above $1200^{\circ} \mathrm{C}$. Other ores are very similar, 20$40 \%$ liquid phase at $1250^{\circ} \mathrm{C}$ and $55-60 \%$ at $1300^{\circ} \mathrm{C}$. The chemical composition of the slag phase (or liquid phase) varies with the temperature and ore.

\subsection{Effect of Chemical Composition on Liquidus Pro- jection}

Many studies ${ }^{15-18)}$ were carried out on the effect of mineral composition on the sintering behaviors. It was reported that the mass of liquid phase decreases with decreasing the $\mathrm{SiO}_{2}$ and increasing the $\mathrm{MgO}$, and $\mathrm{Al}_{2} \mathrm{O}_{3}$ has less effect on the formation of liquid phase. Kongoli and Yazawa ${ }^{19)}$ has reported the liquidus surface of $\mathrm{SiO}_{2}-\mathrm{CaO}-\mathrm{Fe}_{2} \mathrm{O}_{3}-\mathrm{FeO}$ slag containing $\mathrm{Al}_{2} \mathrm{O}_{3}, \mathrm{MgO}$ and $\mathrm{Cu}_{2} \mathrm{O}$, which is very common system in pyometallurgy. In their system studied, the oxygen partial
Table 1. Composition of the eight iron ores selected, mass $\%$.

\begin{tabular}{ccccccccccc}
\hline Ore & Water & LOI & $\mathrm{TFe}$ & $\mathrm{FeO}$ & $\mathrm{SiO}_{2}$ & $\mathrm{CaO}$ & $\mathrm{MgO}$ & $\mathrm{A}_{2} \mathrm{O}_{3}$ & $\mathrm{~S}$ & $\mathrm{P}$ \\
\hline $\mathrm{A}$ & 2.81 & 0.66 & 62.64 & 28.01 & 7.52 & 1.22 & 4.54 & 1.14 & 1.61 & 0.010 \\
$\mathrm{~B}$ & 3.16 & 3.61 & 62.23 & 0.53 & 4.38 & 0.10 & 0.12 & 3.59 & 0.01 & 0.046 \\
$\mathrm{C}$ & 1.07 & 0.66 & 65.75 & 0.80 & 5.28 & 0.10 & 0.08 & 1.20 & 0.01 & 0.067 \\
$\mathrm{D}$ & 2.70 & 0.97 & 61.19 & 23.35 & 6.26 & 0.40 & 5.98 & 0.98 & 0.04 & 0.010 \\
$\mathrm{E}$ & 7.94 & 1.05 & 63.68 & 22.42 & 10.02 & 0.55 & 0.64 & 1.81 & 0.01 & 0.023 \\
$\mathrm{~F}$ & 0.36 & 2.22 & 63.33 & 1.26 & 3.71 & 0.21 & 0.14 & 1.61 & 0.09 & 0.060 \\
$\mathrm{G}$ & 7.04 & 4.86 & 56.00 & 7.60 & 12.45 & 1.75 & 1.53 & 1.64 & 0.49 & 0.160 \\
$\mathrm{H}$ & 8.10 & 3.50 & 59.53 & 14.14 & 6.40 & 4.80 & 2.42 & 0.78 & 0.48 & 0.680 \\
\hline
\end{tabular}

Table 2. Composition of the ores used in calculation with Factsage, $\operatorname{mass} \%$.

\begin{tabular}{crrrrrr}
\hline Ore & $\mathrm{Fe}_{2} \mathrm{O}_{3}$ & $\mathrm{Fe}_{3} \mathrm{O}_{4}$ & $\mathrm{SiO}_{2}$ & $\mathrm{CaO}$ & $\mathrm{MgO}$ & $\mathrm{A}_{2} \mathrm{O}_{3}$ \\
\hline A & 0.52 & 74.4 & 6.67 & 13.36 & 4.03 & 1.01 \\
$\mathrm{~B}$ & 82.44 & 1.63 & 4.14 & 8.28 & 0.11 & 3.39 \\
$\mathrm{C}$ & 82.24 & 2.32 & 4.76 & 9.52 & 0.07 & 1.08 \\
$\mathrm{D}$ & 8.67 & 68.1 & 5.66 & 11.32 & 5.40 & 0.89 \\
$\mathrm{E}$ & 13.42 & 59.70 & 8.28 & 16.56 & 0.53 & 1.49 \\
$\mathrm{~F}$ & 83.59 & 3.93 & 3.59 & 7.19 & 0.14 & 1.56 \\
$\mathrm{G}$ & 45.68 & 20.46 & 10.40 & 20.80 & 1.28 & 1.37 \\
$\mathrm{H}$ & 35.80 & 43.04 & 6.05 & 12.09 & 2.29 & 0.74 \\
\hline
\end{tabular}

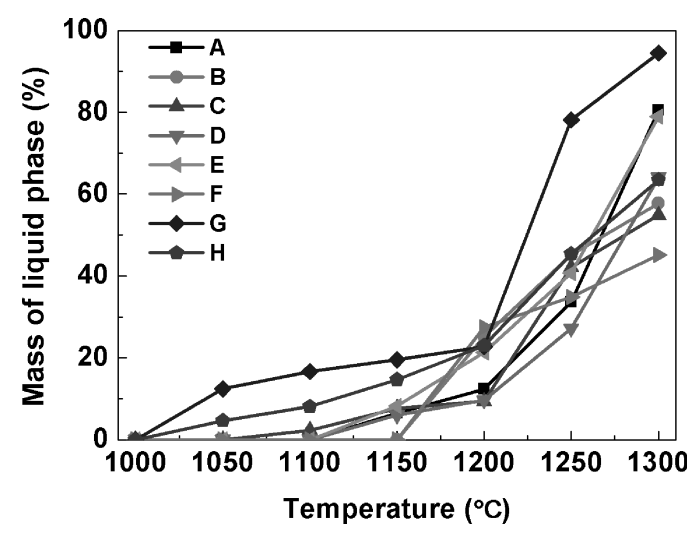

Fig. 1. Mass of liquid phase verse temperature for eight ores.

pressures were fixed at $10^{-8}, 10^{-7}$, and $10^{-6}$ atm, meaning a very reductive atmosphere and a relative high amount of $\mathrm{FeO}$. However, the $\mathrm{FeO}$ in the sinter is not expected to reach a high value for resulting in worsen the formation of calcium ferrite. As reported by Hsieh and Whiteman, ${ }^{20)}$ the optimal oxygen partial pressure which is beneficial to the formation of calcium ferrite should be about $5 \times 10^{-3}$ atm. In present calculations, the atmosphere was fixed at a medium oxidation, in which the pressure was fixed at $10^{-2}$. The effects of mineral composition on the melting behavior were calculated and the results are shown in Figs. 2-8. Comparing this results with the liquidus surface reported previously, ${ }^{19)}$ the liquidus lines move off the line between $\mathrm{SiO}_{2}$ and $\mathrm{Fe}_{2} \mathrm{O}_{3}$. The reason for this is that the less $\mathrm{FeO}$ contained in the system and the less liquid phase of $\mathrm{FeSiO}_{3}$ formed.

Comparing Fig. 2 with Fig. 3, it was found that the liquid 




Fig. 2. Liquid phase projection of $\mathrm{CaO}-\mathrm{SiO}_{2}-\mathrm{Fe}_{2} \mathrm{O}_{3}$ system.

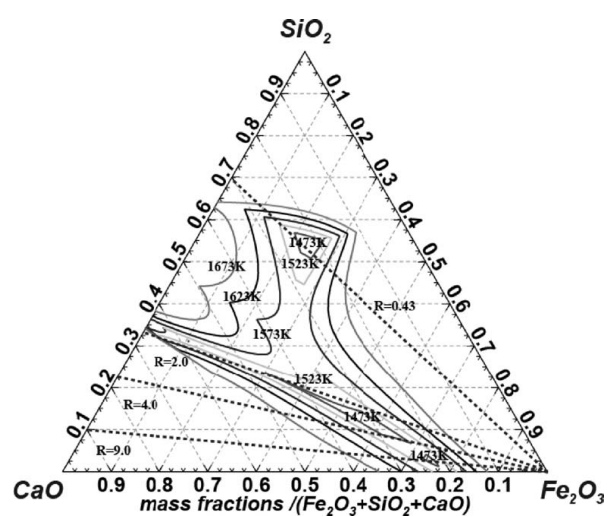

Fig. 3. Liquid phase projection of $\mathrm{CaO}-\mathrm{SiO}_{2}-\mathrm{Fe}_{2} \mathrm{O}_{3}\left(2 \% \mathrm{Al}_{2} \mathrm{O}_{3}\right)$ system.

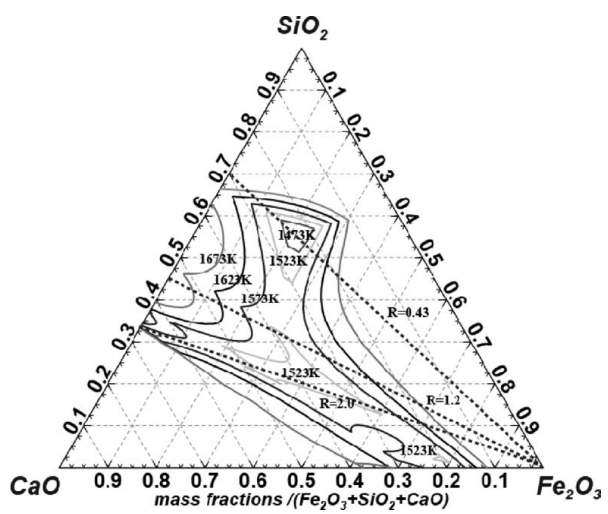

Fig. 4. Liquid phase projection of $\mathrm{CaO}-\mathrm{SiO}_{2}-\mathrm{Fe}_{2} \mathrm{O}_{3}\left(4 \% \mathrm{Al}_{2} \mathrm{O}_{3}\right)$ system.



Fig. 5. Liquid phase projection of $\mathrm{CaO}-\mathrm{SiO}_{2}-\mathrm{Fe}_{2} \mathrm{O}_{3}\left(2 \% \mathrm{Al}_{2} \mathrm{O}_{3}\right.$, $2 \% \mathrm{MgO}$ ) system.

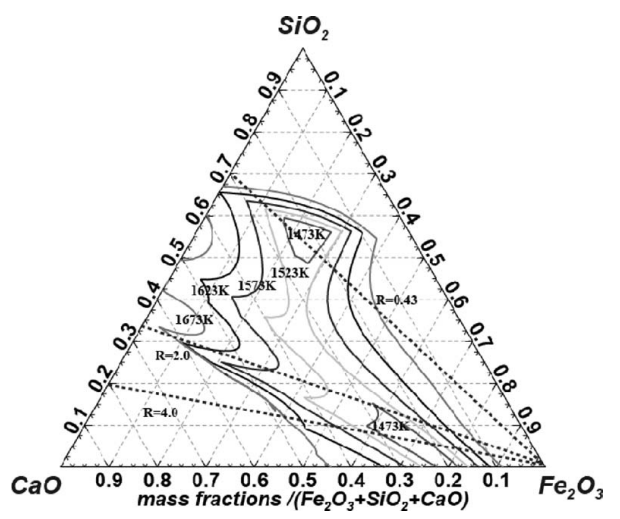

Fig. 6. Liquid phase projection of $\mathrm{CaO}-\mathrm{SiO}_{2}-\mathrm{Fe}_{2} \mathrm{O}_{3}\left(2 \% \mathrm{Al}_{2} \mathrm{O}_{3}\right.$, $4 \% \mathrm{MgO}$ ) system.

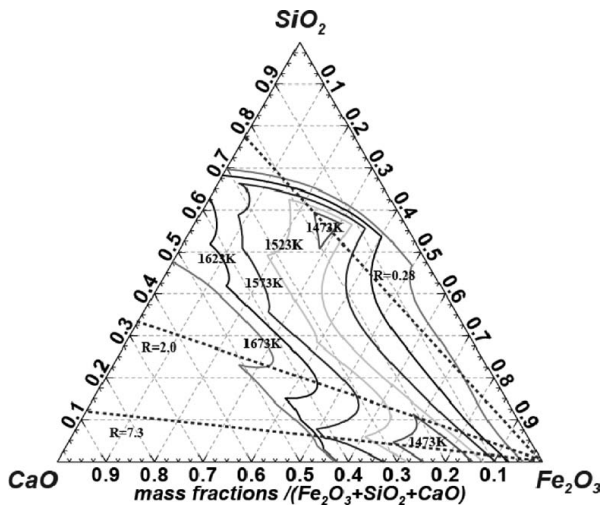

Fig. 7. Liquid phase projection of $\mathrm{CaO}-\mathrm{SiO}_{2}-\mathrm{Fe}_{2} \mathrm{O}_{3}\left(2 \% \mathrm{Al}_{2} \mathrm{O}_{3}\right.$, $8 \% \mathrm{MgO}$ ) system.

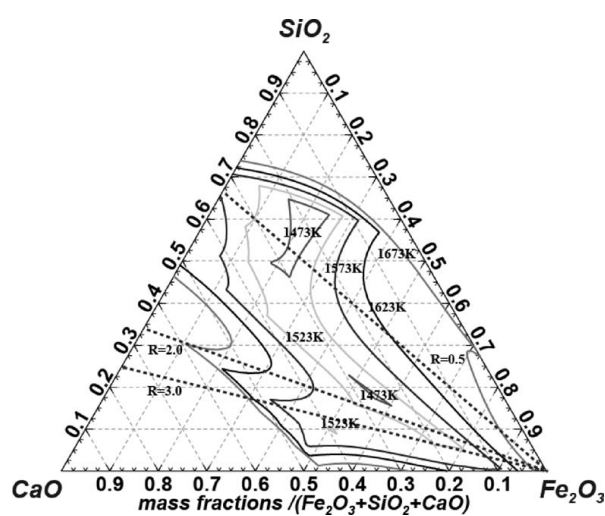

Fig. 8. Liquid phase projection of $\mathrm{CaO}-\mathrm{SiO}_{2}-\mathrm{Fe}_{2} \mathrm{O}_{3}\left(6 \% \mathrm{Al}_{2} \mathrm{O}_{3}\right.$, $8 \% \mathrm{MgO}$ ) system.

phase zone expands to the low $\mathrm{Fe}_{2} \mathrm{O}_{3}$ direction when 2\% $\mathrm{Al}_{2} \mathrm{O}_{3}$ was mixed in the $\mathrm{SiO}_{2}-\mathrm{CaO}-\mathrm{Fe}_{2} \mathrm{O}_{3}$ system. It means that it is good for generating liquid phase by adding some $\mathrm{Al}_{2} \mathrm{O}_{3}$ in the low grade iron ores. The liquid phase zones at $1200^{\circ} \mathrm{C}$ with $\mathrm{Al}_{2} \mathrm{O}_{3}$ scatter in three discrete positions and has a long and narrow area. The three liquid zones at $1200^{\circ} \mathrm{C}$ refers to zone A with $25 \% \mathrm{Fe}_{2} \mathrm{O}_{3}$ and the basicity of 0.43 , zone $\mathrm{B}$ with $60 \%-70 \% \mathrm{Fe}_{2} \mathrm{O}_{3}$ and the basicity of 2-4, and zone $\mathrm{C}$ with $70 \%-80 \% \mathrm{Fe}_{2} \mathrm{O}_{3}$ and the basicity of 9 individually. Zone $\mathrm{B}$ is the reasonable area for the current sintering industry, and zone $\mathrm{C}$ is reasonable for the initial liquid phase. Zone $\mathrm{B}$ and $\mathrm{C}$ merge together as the temperature increases to $1250^{\circ} \mathrm{C}$, and finally zone A joins them into a unique area when the temperature is up to $1300^{\circ} \mathrm{C}$. Figure 4 shows the 
liquid phase projection for the case with $4 \% \mathrm{Al}_{2} \mathrm{O}_{3}$. Comparing it with Fig. 3, it was found that the liquid zones $\mathrm{B}$ and $\mathrm{C}$ in the case of $2 \% \mathrm{Al}_{2} \mathrm{O}_{3}$ at $1200^{\circ} \mathrm{C}$ disappear, only zone $\mathrm{A}$ of that still exists. There are two zones of liquid phases at $1250^{\circ} \mathrm{C}$. One is with $20 \%-30 \% \mathrm{Fe}_{2} \mathrm{O}_{3}$ and the basicity of 0.43 , and the other one is with $30 \%-60 \% \mathrm{Fe}_{2} \mathrm{O}_{3}$ and the basicity of 1.2-2. The latter zone is close to the reasonable area for the current sintering. However, the suitable sintering temperature for the case with $4 \% \mathrm{Al}_{2} \mathrm{O}_{3}$ is higher than that with $2 \% \mathrm{Al}_{2} \mathrm{O}_{3}$. This phenomenon indicates that a little $\mathrm{Al}_{2} \mathrm{O}_{3}$ can improve the sintering, but more $\mathrm{Al}_{2} \mathrm{O}_{3}$ will worsen it. The effect of $\mathrm{MgO}$ on the sintering behavior was calculated and shown in Fig. 5, which $2 \% \mathrm{MgO}$ and $2 \% \mathrm{Al}_{2} \mathrm{O}_{3}$ are added into the mixture. There are two liquid phase zone at $1200^{\circ} \mathrm{C}$. Zone A is with $20 \%-30 \% \mathrm{Fe}_{2} \mathrm{O}_{3}$ and the basicity of 0.43 , and zone $\mathrm{B}$ is with $30 \%-80 \% \mathrm{Fe}_{2} \mathrm{O}_{3}$ and the basicity above 2.0. Zone $\mathrm{B}$ merges with $\mathrm{C}$ in the case with $2 \% \mathrm{Al}_{2} \mathrm{O}_{3}$ into a new zone $\mathrm{B}$, which is a very big area for sintering. It seems that the adding of $\mathrm{MgO}$ is good for the forming of liquid phase. However, the case with $2 \% \mathrm{Al}_{2} \mathrm{O}_{3}$ and $4 \% \mathrm{MgO}$ shown in Fig. 6 give an interesting phenomenon. The liquid phase zone in the $\mathrm{Fe}_{2} \mathrm{O}_{3}$ corner at $1200^{\circ} \mathrm{C}$ becomes short and wide. The liquid zone at $1250^{\circ} \mathrm{C}$ merges into an unique area and move to the $\mathrm{Fe}_{2} \mathrm{O}_{3}$ corner. These changes have some effect on sintering, because in the practical sintering, there are some un-melting $\mathrm{Fe}_{2} \mathrm{O}_{3}$ in the iron ore sinter, the mass fraction of $\mathrm{Fe}_{2} \mathrm{O}_{3}$ in the liquid phase is only $40 \%-60 \%$. The liquid phase zone at $1200^{\circ} \mathrm{C}$ move to the area with $60 \%-80 \%$ $\mathrm{Fe}_{2} \mathrm{O}_{3}$. This change may worsen the sintering. This tendency is apparent when the $8 \% \mathrm{MgO}$ and $2 \% \mathrm{Al}_{2} \mathrm{O}_{3}$ is added into the system. All the liquid zone move to the $\mathrm{Fe}_{2} \mathrm{O}_{3}$ corner. The $1200^{\circ} \mathrm{C}$ liquid phase area moves to the area with $70 \%-90 \%$ $\mathrm{Fe}_{2} \mathrm{O}_{3}$, and even the $1250^{\circ} \mathrm{C}$ liquid phase zone move to the area with $>60 \% \mathrm{Fe}_{2} \mathrm{O}_{3}$ when the basicity is above 2.0. For this case, the reasonable basicity should be closed to 1 . If more $\mathrm{Al}_{2} \mathrm{O}_{3}$ added into the mixture, that is $6 \% \mathrm{Al}_{2} \mathrm{O}_{3}$ and $8 \%$ $\mathrm{MgO}$, the liquid phase zones move to the opposite direction of the $\mathrm{CaO}$ corner. There are two liquid phase zones at $1200^{\circ} \mathrm{C}$. Comparing Fig. 7 with Fig. 8, it was founded that zone A with about $20 \% \mathrm{Fe}_{2} \mathrm{O}_{3}$ and the basicity of 0.5 expands, and zone $\mathrm{B}$ with $50-60 \% \mathrm{Fe}_{2} \mathrm{O}_{3}$ and the basicity of $<1.0$ become a very narrow area. The reasonable sintering condition in this case is with the basicity of $<1.0$ and the temperature of $>1250^{\circ} \mathrm{C}$. The effect of $\mathrm{SiO}_{2}$ on the liquid phase forming in the sintering depends on the grade of iron ores. For the high grade iron ore, the initial liquid phase close to the $\mathrm{Fe}_{2} \mathrm{O}_{3}$ corner, the increase of $\mathrm{SiO}_{2}$ results in the liquid phase moving to $\mathrm{SiO}_{2}$ corner, meaning that the initial liquid phase is beyond the low temperature liquid phase zone. For the low grade iron ores, the initial liquid phase locates at the bottom of the low temperature liquid phase, the increase of the $\mathrm{SiO}_{2}$ makes the initial liquid phase move right to the low temperature liquid phase, meaning improve the sintering. From the above discussions, it is indicated that the mass of liquid phase increase first and then decrease with increasing the $\mathrm{Al}_{2} \mathrm{O}_{3}$. $\mathrm{MgO}$ has the same regularity with $\mathrm{Al}_{2} \mathrm{O}_{3}$. The iron ores with more $\mathrm{MgO}$ and $\mathrm{Al}_{2} \mathrm{O}_{3}$ is suitable to produce low basicity even acid sinter. The suitable $\mathrm{SiO}_{2}$ content in the raw material should be considered by combining the iron ore grade. The regularity calculated is similar to that reported, but the further validation is needed.

\section{Experimental}

There is no direct method to measure the mass of liquid phase in the mixture of solid and liquid phases up to now. Here an indirect method, in which the relationship between the height of the sample and the temperature is measured, was used. ${ }^{21)}$ This method is always used to measure the melting behavior of the slag. The equipment of melting behavior for the mixture of the iron ore and flux is shown in Fig. 9, which can be divided into image capturing, heating system, and the sample holder. The heater is made of platinum, and the maximum temperature achieved is $1600^{\circ} \mathrm{C}$. The samples are made into a cylindrical of $\Phi 3 \mathrm{~mm} \times \mathrm{H} 3 \mathrm{~mm}$. The air atmosphere was adopted during the measurement.

The samples were put on the sample holder and push it into the heating zone. In this measurement, the heating rate was fixed at $10^{\circ} \mathrm{C} / \mathrm{min}$. The sample was heated in the furnace according to the program fixed in the controller; it shrinks due to the forming of liquid phase. According to the method used for measuring the melting features of slag, the temperature for initial melting, half height, and end of melting are defined individually as the temperature when the height of the sample becomes $10 \%, 50 \%$, and $90 \%$ of the original height. The images captured in the measurement are shown in Fig. 10. Each sample was measured twice and the average result was used in order to get an accurate result.

\section{Validations and Discussions}

The results for each sample were shown in Fig. 11, and the melting parameters defined are summarized in Table $\mathbf{3}$. It shows that the liquid phases increase with increasing the temperature. As for the dependency of the temperature on the shrinkage ratio, samples $\mathrm{E}$ and $\mathrm{G}$ are similar. It is that the rate of creating liquid phase decrease with increasing the temperature. On the opposite, samples B, C, D, F, and H are similar, the rate of creating liquid phase increase with increasing the temperature. Comparing the chemical composition of the eight samples, it was found that sample E and $\mathrm{G}$ have high $\mathrm{SiO}_{2}$, about $10-12 \%$. It means more $\mathrm{CaO}$ is added into the samples for basicity balance. For other samples, the $\mathrm{SiO}_{2}$ is about 3-7\%. Figure 12 shows the liquid phase projection of the $\mathrm{CaO}-\mathrm{SiO}_{2}-\mathrm{Fe}_{2} \mathrm{O}_{3}$ system. The dish

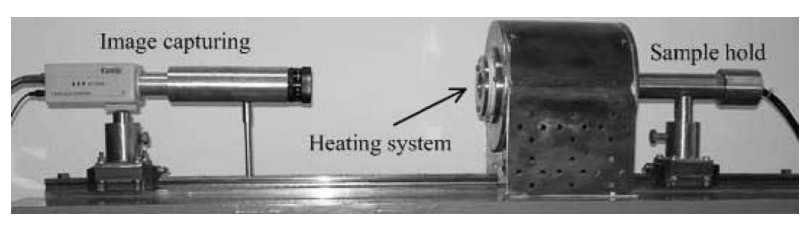

Fig. 9. Melting features measurement system.



Fig. 10. Image captured during the measurement of melting behavior. 


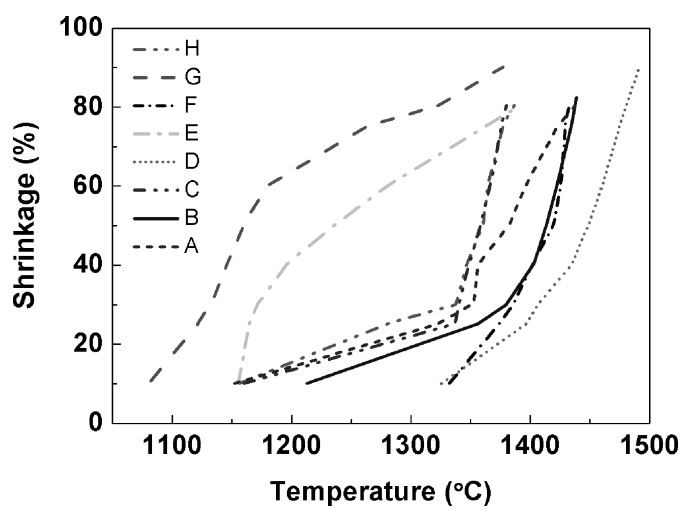

Fig. 11. Shrinkage of the samples versus temperature.

Table 3. The melting features of iron ore samples.

\begin{tabular}{ccccccccc}
\hline Samples & A & B & C & D & E & F & G & H \\
\hline $\mathrm{T}_{10 \%}$ & 1152 & 1213 & 1160 & 1325 & 1155 & 1332 & 1082 & 1156 \\
$\mathrm{~T}_{50 \%}$ & 1382 & 1413 & 1358 & 1448 & 1236 & 1419 & 1162 & 1376 \\
$\mathrm{~T}_{80 \%}$ & 1436 & 1438 & 1380 & 1479 & 1389 & 1432 & 1322 & 1419 \\
\hline
\end{tabular}

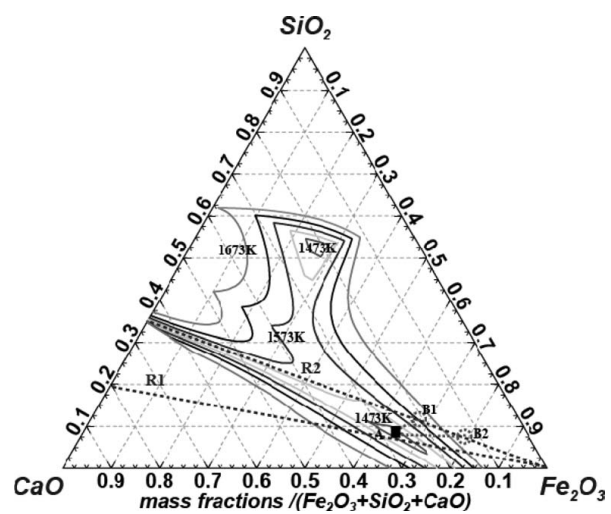

Fig. 12. Liquid phase projection of $\mathrm{CaO}-\mathrm{SiO}_{2}-\mathrm{Fe}_{2} \mathrm{O}_{3}$ system.

line R1 and R2 represents the basicity of 6 and 2 in the system individually. The solid dark square A stands for the initial liquid phases for low and high $\mathrm{SiO}_{2}$ samples, and zones B1 and B2 represent the ending liquid phases for the high and low $\mathrm{SiO}_{2}$ samples. The liquid phase increases with increasing the temperature. For both of the two kind samples, the basicity of the liquid phase is as high as $3-4$. Both of them move to line R2 as the temperature increases. Comparing the change of liquid phase of high $\mathrm{SiO}_{2}$ with that of the low $\mathrm{SiO}_{2}$, it indicates that high $\mathrm{SiO}_{2}$ samples create more initial liquid phases at $1200-1250^{\circ} \mathrm{C}$, and the increases of that become slow with increasing the temperature. This factor, mass of liquid phase, result in the tendency of the shrinkage of the iron ore samples verse the temperature. The more initial liquid phase and high viscosity make for the decrease of shrinkage rate with the temperature.

From Table 3, it is found that samples A, C, E, G, and H has low $\mathrm{T} 10 \%$, meaning these samples create liquid phase easily at low temperature. These measurements agree very well with the calculation shown in Fig. 1, in which samples $\mathrm{G}$ and $\mathrm{H}$ begin to create the liquid phase from $1000^{\circ} \mathrm{C}$ and samples A, C, and $\mathrm{E}$ create the liquid phase from $1050^{\circ} \mathrm{C}$. As for T50\%, samples E and $\mathrm{G}$ are much lower than others.
These measurements also agree well with the calculation when the temperature is above $1280^{\circ} \mathrm{C}$, almost $50 \%$ of liquid phase formed for samples $\mathrm{G}$ and E. Samples C, E, G have low $\mathrm{T} 90 \%$, and sample D have high of that, while the calculation has some deviation with these measurements. The probable reason is that the shrinkage ratio not only relates to the ratio of liquid phase, but also the viscosity of the liquid phase, the contact angle between the liquid phase and the sample holder, and some other factors. The relationship between the shrinkage and the liquid phase ratio is hard to be qualified due to its complex relations up to now. Comparing Table 3 with Fig. 1, it is indicate that the calculation of liquid phase can represent ability of the liquid phase forming during the sintering, especially in the initial step of melting.

Comparing the Fig. 12 with Fig. 1, the calculation shows that ore $\mathrm{G}$ creates more liquid phase than other ores between $1200^{\circ} \mathrm{C}$ and $1300^{\circ} \mathrm{C}$. The order of mass of liquid phase formed from more to less at $1300^{\circ} \mathrm{C}$ is $\mathrm{G}, \mathrm{E}, \mathrm{A}, \mathrm{H}, \mathrm{D}, \mathrm{B}, \mathrm{C}$, and $\mathrm{F}$. According to the measurements which is shown in Fig. 12, this order is G, E, H, A, C, B, F and D. The measurements is very similar to the calculation except for sample D. It means that the thermodynamic calculation can give a useful and relatively accurate information on the ability of liquid phase forming.

As for the effect of chemical composition on the formation of liquid phase, the good agreement can also be got. From Table 1, it can be found that ores B, E, G, and F have high $\mathrm{Al}_{2} \mathrm{O}_{3}$ content, in which ore $\mathrm{B}$ is as high as 3.59 , and ores $\mathrm{E}, \mathrm{G}$, and $\mathrm{F}$ are very closed to each other, individually $1.81,1.64$, and 1.61. Figure 11 shows that ore $\mathrm{B}$ have the higher initial melting point and end melting point than others. Ores $\mathrm{E}$ and $\mathrm{G}$ have high $\mathrm{SiO}_{2}$ content, the melting property was improved. Ore $\mathrm{F}$ have a much lower $\mathrm{SiO}_{2}$ content than ore $\mathrm{B}$, however, with the effect of low $\mathrm{Al}_{2} \mathrm{O}_{3}$, the melting property of ore $\mathrm{F}$ is similar to ore $\mathrm{B}$, other than much lower than ore $\mathrm{B}$. Ores $\mathrm{D}, \mathrm{A}, \mathrm{H}$, and $\mathrm{G}$ have high $\mathrm{MgO}$ content. The $\mathrm{MgO}$ content of Ore $\mathrm{D}$ is as high as 5.98, that of ore $\mathrm{A}$ is 4.54, and that of ores $\mathrm{H}$ and $\mathrm{G}$ is 2.42 and 1.53. From Fig. 11 and Table 3, it can be found that ore D has the highest $\mathrm{T}_{10 \%}, \mathrm{~T}_{50 \%}$, and $\mathrm{T}_{90 \%}$. Ore $\mathrm{A}$ also has the higher melting point than ores $\mathrm{H}$ and $\mathrm{G}$. Summarizing these regularities, indicates that the mass of liquid phase decreases with increasing the $\mathrm{Al}_{2} \mathrm{O}_{3}$ and $\mathrm{MgO}$ to a critical level, as shown in Figs. 2-8.

\section{Deviation between the Equilibrium Calculation and the Non-equilibrium Reactions}

As mentioned in the introduction of this study, the reactions in the real industrial sintering plant are not uniform, and are governed by the rate limiting process. The calculations by Factsage is equilibrium. Takagi ${ }^{22)}$ studied the kinetics on the formation of calcium ferrite, it was found that the solid reactions during the sintering accord with Jander equation $^{22)}$ which is expressed as:

$$
\left\{1-(1-\alpha)^{1 / 3}\right\}^{2}=k \cdot t
$$

where $\alpha, \mathrm{K}$, and $\mathrm{t}$ represent the product ratio, the rate constant, and the reaction time (in hour). The activation energies calculated for $\mathrm{CaO}: \mathrm{Fe}_{2} \mathrm{O}_{3}=1: 1$ and $\mathrm{CaO}: \mathrm{Fe}_{2} \mathrm{O}_{3}=1: 2$ are 


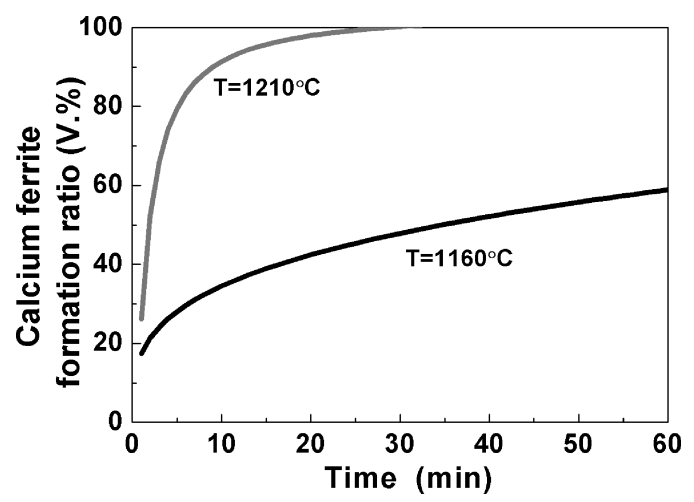

Fig. 13. Relationship between the calcium ferrite formation ratio and the sintering time.

$250.3 \mathrm{~kJ} / \mathrm{mol}$ and $281.7 \mathrm{~kJ} / \mathrm{mol}$. According to this report, more than 10 hours are needed for obtaining a uniform calcium ferrite phase through solid phase reactions. ${ }^{22)} \mathrm{Guo}^{23)}$ studied the rate of calcium ferrite formation in sintering process, in which the temperature is above $1200^{\circ} \mathrm{C}$ and the liquid phase of calcium ferrite formed. Under this condition, the rate of calcium ferrite formation is much faster than the solid phase reactions. The relationship between the calcium ferrite formation ratio and the time is expressed as followings according to the experiments.

$\alpha=17.357 \cdot t^{0.2983}$ when the temperature is $1160^{\circ} \mathrm{C}^{22)}$

$\alpha=105.004 \cdot \exp \left(\frac{-1.391}{t}\right)$ when the temperature is $1210^{\circ} \mathrm{C}^{23)}$

where $t$ is the sintering time in minute. These relationships are plotted in Fig. 13. The holding time of the samples in the furnace was about 135 minutes, and the time for the samples staying in the solid phase is about 110 minutes. According to Takagi's study, 135 mintes is far from the time needed to get equilibrium. While the time for the samples staying with the liquid phase formation $\left(>1200^{\circ} \mathrm{C}\right)$ is about 25 minutes. According to Fig. 13, the equilibrium was almost reached. Therefore, the calculation of the liquid phase formation is very similar to the measurements.

\section{Conclusions}

The liquid phase formulation during the iron ore sintering were studied by using the FACTSage software, and the experiments were carried out for the validation. The conclusions can be summarized as followings:

(1) The calculation shows that the liquid phase formed during the sintering increases with increasing the sintering temperature, the content of liquid phase formed is about $25 \%-70 \%$ at $1250^{\circ} \mathrm{C}$ due to their chemical composition.
(2) According to the experiments, the calculations of the mass of liquid phase generation cannot give a good and accurate agreement quantificationally with the measurement of the melting behavior of the sample, however, for the ability of the liquid phase formation during the sintering, the calculations can give a good qualitative results, especially in the temperature of melting begin and the temperature of $50 \%$ shrinkage. The calculations reported in this study can be used to estimate the sintering behavior of the iron ores under a certain industrial condition to reduce the extra experiments.

(3) The fraction of $\mathrm{SiO}_{2}$ has great effect on forming of liquid phase. The more $\mathrm{SiO}_{2}$, the easier to form liquid phase. $\mathrm{MgO}$ and $\mathrm{Al}_{2} \mathrm{O}_{3}$ also have effect on the melting property of the iron ore, which is determined by their content. The calculations by Factsage can give some good explanations on the phenomenon of the melting behavior of different samples.

\section{Acknowledgments}

The authors are especially grateful to Fundamental Research Funds for the Central Universities Fund (Grant No. CDJRC10130009) and Key Project of Chinese National Programs for Fundamental Research and Development (Grant No. 2007CB613503).

\section{REFERENCES}

1) J. Hanchart, V. Leroy and A. bragard: Metallurgical report of C. N. R. M., (1967), 3.

2) D. H. Lister and F. P. Glasser: Trans. Br. Ceram. Soc., 66 (1967), 293.

3) Y. Ishikawa, Y. Shimomura, M. Sasaki, Y. Hida and H. Toda: The 42th Ironmaking Proc., AIST, Warrendale, PA, (1983), 17.

4) P. R. Dawson: Ironmaking Steelmaking, 20 (1993), 137.

5) P. R. Dawson: Ironmaking Steelmaking, 20 (1993), 144.

6) P. R. Dawson: Ironmaking Steelmaking, 20 (1993), 135.

7) P. R. Dawson: Ironmaking Steelmaking, 20 (1993), 150.

8) S. Wu, Y. Liu, J. Du, K. Mi and H. Lin: J. Univ. Sci. Technol. Beijing, 24 (2002), 258.

9) S. Wu, Y. Liu, J. Du, K. Mi and H. Lin: J. Univ. Sci. Technol. Beijing, 24 (2002), 254.

10) S. Wu, J. Du, H. Ma, Z. Zhang and H. Chen: J. Univ. Sci. Technol. Beijing, 27 (2005), 169.

11) S. Wu, J. Du, H. Ma, J. Tian and H. Xu: J. Univ. Sci. Technol. Beijing, 27 (2005), 291.

12) E. Kasal, J. R. William and F. G. John: ISIJ Int., 29 (1989), 33.

13) F. Kongoli, I. McBow, R. Budd and S. Llubani: Sohn Int. Symp. Advanced Processing of Metals and Materials, Vol. 7, TMS, Warrendale, PA, (2006), 245.

14) http://www.factsage.com/.

15) M. Matsumura, M. Hoshi and T. Kawaguchi: ISIJ Int., 45 (2005), 594.

16) M. S. De Magalhaes and P. R. G. Brandao: Miner. Eng., 16 (2003), 1251.

17) B. Nandy, M. K. Chaudhury, J. Paul and D. Bhattacharjee: Metall. Mater. Trans. B, 40 (2009), 662.

18) Y. Hida, J. Okazaki, K. Ito and S. Hirakawa: Tetsu-to-Hagané, 78 (1992), 1013.

19) F. Kongoli and A. Yazawa: Metall. Mater. Trans. B, 32 (2001), 583.

20) L. H. Heieh and J. A. Whiteman: ISIJ Int., 29 (1989), 24.

21) S. Chu, H. Liu, S. Diao and T. Xu: J. Univ. Sci. Technol. Beijing, 2 (1995), 19.

22) S. Takagi, J. Hirao and Y. Tanaka: Tetsu-to-Hagané, 53 (1967), 729.

23) X. Guo and H. Du: J. Univ. Sci. Technol. Beijing, 20 (1998), 247. 